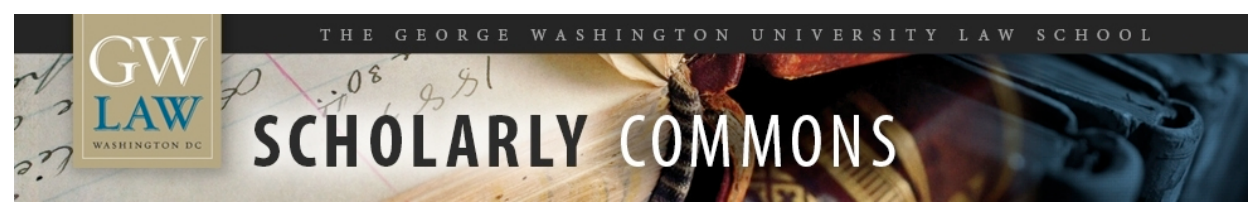

\title{
The Bonding Effect in Cross-Listed Chinese Companies: Is it Real?
}

Donald C. Clarke

George Washington University Law School, dclarke@law.gwu.edu

Follow this and additional works at: https://scholarship.law.gwu.edu/faculty_publications

Part of the Law Commons

\section{Recommended Citation}

Clarke, Donald C., The Bonding Effect in Cross-Listed Chinese Companies: Is it Real? (December 31, 2015). GWU Law School Public Law Research Paper No. 2015-55; GWU Legal Studies Research Paper No. 2015-55. Available at SSRN: http://ssrn.com/abstract=2710717

This Article is brought to you for free and open access by the Faculty Scholarship at Scholarly Commons. It has been accepted for inclusion in GW Law Faculty Publications \& Other Works by an authorized administrator of Scholarly Commons. For more information, please contact spagel@law.gwu.edu. 
The Bonding Effect in Cross-Listed Chinese Companies: Is It Real?

Donald Clarke

George Washington University Law School

Dec. 31, 2015

\begin{abstract}
A common explanation offered for PRC companies' listing overseas is that they receive a price premium because listing overseas demonstrates a willingness to submit to the more shareholder-protective regulatory regime of the foreign jurisdiction and stock market. This explanation is commonly known as the bonding hypothesis. There is some empirical support for the proposition that listing overseas does indeed bring a price premium, although issues of causality are difficult to sort out. If it is true that investors view an overseas listing of a Chinese firm as something worth paying a premium for, the question remains, however, as to whether that view is well founded. Investors in overseas markets may find themselves left out in the cold when things go wrong, and indeed the Risk Factors section of PRC firms' IPO prospectuses routinely caution investors that successfully suing the company or its management will be difficult or impossible.

This paper will examine the degree to which Chinese listed companies and their management do in fact, in a practical and realistic way, bind themselves to overseas state and market norms when such companies list abroad. It will argue that the actual binding effect of an overseas listing is small and that investors are mistaken to pay a premium for it. This conclusion, if correct, has at least two important implications beyond China. First, it casts into doubt the semi-strong form of the efficient capital markets hypothesis, because it means that there is publicly available information that does not seem to be adequately incorporated into stock prices. Second, it suggests that the bonding hypothesis needs to be examined on an empirical, country-by-country basis to see whether the bonding is in fact anything more than an illusion.
\end{abstract}


The Bonding Effect in Cross-Listed Chinese Companies: Is It Real?

1. Introduction

Why do Chinese companies ${ }^{1}$ list abroad, and more specifically, in the United States? One explanation is that they wish to reduce their cost of capital by increasing investor confidence, and cross-listing in the United States accomplishes that by credibly committing the company to a regime of enhanced disclosure and greater exposure to a shareholder-protective legal regime (the bonding hypothesis).

The cause-and-effect proposition of the bonding hypothesis has been challenged from time to time, notably in a recent paper by Licht et al. (2013). This paper takes a different tack. It accepts for the sake of argument that investors believe that cross-listing produces the promised benefits and are accordingly willing to pay more for cross-listed companies. ${ }^{2}$ It asks instead whether, in the case of Chinese cross-listings in the United States, that belief is well-founded. If not, then it follows that the stock of Chinese companies in United States markets is generally overpriced both in the United States and in China (if the company has also listed stock there), and that the semi-strong form of the efficient capital markets hypothesis, which holds that all publicly available information is rapidly incorporated into stock prices, does not hold in this particular case.

2. Analysis

2.1. Cross-listing generally

A number of explanations have been offered for cross-listing generally, including a desire to overcome inefficiencies in pricing caused by market segmentation, a desire for increased liquidity, a belief that cross-listing will enhance stock prices through the increased availability of information that results from increased analyst and media coverage, a belief that the cost of capital will be reduced through the increased disclosure that comes from cross-listing in a market that requires such disclosure, and the belief that the cost of capital will be reduced because cross-listing can bind the company to a regime that protects minority shareholder interests better than the home jurisdiction. ${ }^{3}$ It is this

\footnotetext{
${ }^{1}$ The term "Chinese [or PRC] company" is used in this study to mean a company headquartered in the People's Republic of China and managed predominantly by Chinese nationals, even though it may be incorporated in another jurisdiction.

${ }^{2}$ This is not necessarily true. Liu et al. (2015) find that firms listed only on Chinese domestic stock exchanges command a higher value than those that are cross-listed on overseas exchanges. On the other hand, Shen et al. (2010) found that there was a cross-listing premium. Resolving the issue is beyond the scope of this chapter.

${ }^{3}$ See generally Dodd (2013).
} 
last theory—the "bonding hypothesis" — - that will be examined in this paper with reference to China.

2.2. The bonding hypothesis

2.2.1. Bonding in general ${ }^{5}$

As applied to cross-listings in the United States, the bonding hypothesis has two parts. First, it states that companies commit to a higher level of disclosure. Second, it states that companies expose themselves to the more investor-protective laws of the United States. Both actions give investors greater confidence and thus lower the cost of capital for cross-listing companies. A typical statement is that of Coffee (2002: 1767):

[C]ross-listing may also be a bonding mechanism by which firms incorporated in jurisdictions with weak protection of minority rights or poor enforcement mechanisms can voluntarily subject themselves to higher disclosure standards and stricter enforcement in order to attract investors who would otherwise be reluctant to invest (or who would discount such stocks to reflect the risk of minority expropriation).

More specifically,

Listing on a U.S. exchange [commits the listing firm to respect minority investor rights and to provide fuller disclosure] because (1) the listing firm becomes subject to the enforcement powers of the Securities and Exchange Commission (SEC); (2) investors acquire the ability to exercise effective and low-cost legal remedies, such as class actions and derivative actions, that are simply not available in the firm's home jurisdiction; and (3) entry into the U.S. markets commits the firm (at least when it lists on an exchange or Nasdaq) to provide fuller financial information in response to SEC requirements and to reconcile its financial statements with U.S. generally accepted accounting principles (GAAP). (Coffee 2002: 1780-81 (internal footnotes omitted))

2.2.2. Bonding as applied to Chinese firms

A number of scholars have attributed the cross-listing of Chinese firms on United States exchanges to precisely this motivation. Moreover, the consensus in the literature seems to be that bonding is more than simply perceived; it is real.

\footnotetext{
${ }^{4}$ The bonding hypothesis is generally credited to Coffee (1999) and Stulz (1999), although Coffee (1999: 674 n.114) notes that Rock (1998) comes up with the "same bonding thesis." Rock's 1998 paper was subsequently published as Rock (2002).

${ }^{5}$ For a particularly helpful review of the literature, see Liu et al. (2015) and its bibliography.
} 
Issuers migrate from "low disclosure" domestic exchanges to "high disclosure" overseas exchanges and voluntarily subject themselves to higher disclosure and corporate governance standards and greater threat of enforcement. Laws and regulations of a foreign jurisdiction, such as the U.S., may effectively deter malfeasance by a foreign issuer's insiders. As a result, cross-listing signals to their investors the issuer's strong commitment not to expropriate the minority shareholders' interests. In accordance with this strategy, many Chinese companies choose to list themselves on overseas stock exchanges, including exchanges in Hong Kong, the U.S., Singapore, and the U.K. Among those foreign exchanges, exchanges in the U.S. and the U.K. are considered to have the highest disclosure standards. (Cai 2007: 102)

[When Chinese firms cross-list], [t]hey become subject to stricter insider trading prohibitions, limitations on tender offers, stricter corporate governance requirements, and private shareholder actions under Rule 10b-5 for fraudulent statements or omissions by the issuers. (Cai 2007: 102)

When a firm from a less strict institutional environment decides to cross-list on a US-based exchange, the firm subjects itself to much stricter reporting requirements and must play by US rules. (Peng and Blevins 2012: 250)

There is some support for the proposition that there is a cross-listing premium for Chinese firms listing in Hong Kong (Sun et al. 2006), a premium that might well exist for Chinese firms listing in the United States as well. But we do not know the reason for this premium. It may not be attributable to bonding, and even if it is, it does not answer the question posed by this paper, which is whether the bonding is real or simply perceived.

2.3. Is bonding by Chinese companies real?

There are a number of reasons for doubting that bonding by Chinese companies when they list in the United States is real. By this I mean two things. First, one of the most frequently cited benefits of bonding-more and better disclosure of corporate information - can be undertaken entirely voluntarily by the company and does not require a listing in the United States. Second, the protection offered to minority shareholders by state and federal law in the United States is illusory. The actors that need to be deterred from expropriatory actions are not realistically subject to suit. I explore each of these themes below.

2.3.1. Bonding through disclosure

The bonding hypothesis states that investors value disclosure and will pay a higher price for companies listed in jurisdictions with high disclosure standards. Yet there is nothing preventing Chinese companies from disclosing all the information required by 
the SEC in companies listed on American exchanges, or from adopting GAAP for presenting their financial results. Leuz and Verrechia (2000) found that when German firms switched from German accounting principles to IAS or GAAP, the market reacted positively even though the firms were not required to do so.

It could be argued that investors will not trust the appearance of disclosure unless it is backed up by the threat of sanctions for misleading disclosures that cross-listing supposedly entails. As I will argue below, however, this threat is largely illusory in the first place, at least for Chinese firms, and so there is no actual distinction in this respect between Chinese firms that list in the United States and subject themselves to U.S. disclosure standards and Chinese firms that remain at home and voluntarily disclose the same information.

2.3.2. Bonding through self-subjection to state and federal law

As noted above, a key element of the bonding hypothesis as applied to China is that listing in the United States imposes a real discipline on Chinese companies and those who manage them ${ }^{6}$ because it exposes them to lawsuits if they fail to act according to the higher U.S. standards. But does it? The question can be examined both generally and with respect to China.

\subsubsection{Generally}

There is skepticism in the literature as to the degree to which cross-listing companies and their senior management really subject themselves to the risk of litigation for violating U.S. standards. ${ }^{7}$ MacNeil (2001) argues that the commitments made by foreign firms listing in London are not as strong as they might first appear. Coffee (2002: 1794-96) notes that both public and private enforcement against foreign firms listed in the United States appeared (as of the time of his writing) to be rare, although he goes on to argue that for various reasons he finds the evidence "far from dispositive". Siegel (2005) examined Mexican companies cross-listed in the United States in the period during and after the crisis of 1994-95. He concluded that the SEC and minority shareholders had not effectively enforced the law against those firms, and that their insiders were not deterred from expropriating corporate resources. Cheng et al. (2014) found that "U.S. listed foreign companies experience securities class action lawsuits at about half the rate as do U.S. firms with similar levels of ex ante litigation risk."

\footnotetext{
${ }^{6}$ The latter group is rarely specifically mentioned, but since companies can only act through people, it is a necessary element of the claim.

${ }^{7}$ See generally Sikochi (2014:3) (citing Licht (2003), Siegel (2005), Licht et al. (2013), \& Leuz (2003)).
} 
There is also the general problem that litigation and sanctions targeting the company do not by themselves punish, and therefore do not deter, the individuals responsible for corporate wrongdoing. As Arlen (2007:3) writes,

Private actions against corporations cannot be justified as a mechanism for ensuring that wrongdoers compensate victims because the burden of this litigation does not fall on wrongdoers. Instead, it falls on the firm's shareholders, many of whom were victims of the fraud. ${ }^{8}$

Thus, even if cross-listing means that sanctions can in fact be imposed on the cross-listed firm, there is no particular reason why investors should be comforted by that fact.

\subsubsection{China}

When it comes to Chinese cross-listed companies, there are a number of reasons for doubting that they and their senior management are in fact subject to public or private enforcement.

\subsection{Prospectus disclosure}

Certainly investors who read the companies' prospectuses can blame only themselves for thinking that companies and their management can be made accountable. I examined a random sample of eleven F-1 statements from Chinese companies listed on U.S. exchanges. ${ }^{9}$ Every single one contained a statement along the lines of the following, in virtually identical language:

Substantially all of our operations are conducted in China, and substantially all of our assets are located in China. A majority of our directors and executive officers are nationals or residents of jurisdictions other than the United States and a substantial portion of their assets are located outside the United States. As a result,

\footnotetext{
${ }^{8}$ Coffee (2006: 1556-61) provides a detailed analysis of which shareholder groups win or lose by the wealth transfer involved when a company pays damages in a shareholder class action.

${ }^{9}$ The set of companies from which I made a random selection is a list purporting to include all Chinese ADR issuers as of Sept. 2014, with "Chinese" apparently applying to companies with the headquarters and principal place of business in China; many were incorporated in non-Chinese jurisdictions such as the Cayman Islands. The list appears at http://topforeignstocks.com/foreign-adrslist/the-full-list-of-chinese-adrs/. The procedure used here is not good for more than a quick and dirty estimate of what the prospectuses of Chinese ADR issuers say, but given the strength of the results I doubt a more rigorous inquiry would show anything different.
}

The companies whose prospectuses I examined are 21Vianet, Autohome, China Sunergy, Ctrip, Hurray! Holding, iDreamSky Technology, New Oriental, Renesola, Trina Solar, and Yingli Green Energy. 
it may be difficult for a shareholder to effect service of process within the United States upon these persons, or to enforce against us or them judgments obtained in United States courts, including judgments predicated upon the civil liability provisions of the securities laws of the United States or any state in the United States. (Autohome 2014: 57)

In other words, Chinese cross-listed companies and their management regularly declare that they do not believe they are realistically subject to discipline imposed by American legal institutions. That should count for something.

\subsection{Enforcement of U.S. judgments}

The confidence of management in their untouchability is well founded. Should investors manage to bring a successful action against a Chinese company or its senior management, they would have to get that judgment enforced where the defendant has assets, i.e., in China. Unlike the home countries of a large number of other cross-listed companies-Canada, Israel, and the United Kingdom, for example, to name some important ones-China does not enforce U.S. court judgments (Clarke 2004, Davis 2015).

\subsection{Experience to date}

As of November 2015, there were approximately 100 Chinese companies listed on the New York Stock Exchange or the Nasdaq, and approximately another 200 traded on the over-the-counter market in the United States. ${ }^{10}$ In order to assess the actual effect of bonding, I hand-collected a set of recent public and private enforcement actions under U.S. securities law against Chinese companies and their senior management. I included not only companies incorporated in China, but also companies controlled by Chinese citizens whose main place of business was China, even though they may have incorporated outside of China. I have attempted to find every case, but as the cases are nowhere systematically collected it is possible I have missed some.

\subsection{Private enforcement}

To assess private enforcement, I examined class actions involving Chinese companies from 1 January 2011 through October 2015 inclusive that were listed on the Securities Class Action Clearinghouse (SCAC) web site. ${ }^{11}$ There has been considerable

\footnotetext{
${ }^{10}$ This datum is from a list of American Depository Receipts of China-based companies available at http://topforeignstocks.com/foreign-adrs-list/the-full-list-of-chinese-adrs/.

${ }^{11}$ The web site is at http://securities.stanford.edu/. Cases listed at this web site do not constitute a complete set of all the cases one would wish to examine in a study of private enforcement of corporate law standards; the site does not list, for example, derivative suits brought by shareholders against management for inflicting damage on the company through connected transactions. On the other hand, listing abroad does not necessarily entail subjecting the company to the corporate law of the
} 
action in the realm of private enforcement, although it has not necessarily been successful. In 2011, a record number of class actions - sixty-two - were filed against foreign issuers. ${ }^{12}$ This is the only recent year in which more than half of the cases against foreign issuers thirty-seven - were against Chinese companies (see Figure 1). That year also marked the beginning of a reversal of a long-term pattern in which foreign issuers were underrepresented as targets (LaCroix 2015). Foreign issuers were overrepresented in 2011, but underrepresented in 2012 and 2013 (Comolli \& Starykh 2014: 9) (see Figure 2). In 2014 and 2015, however, they were overrepresented again (LaCroix 2015).

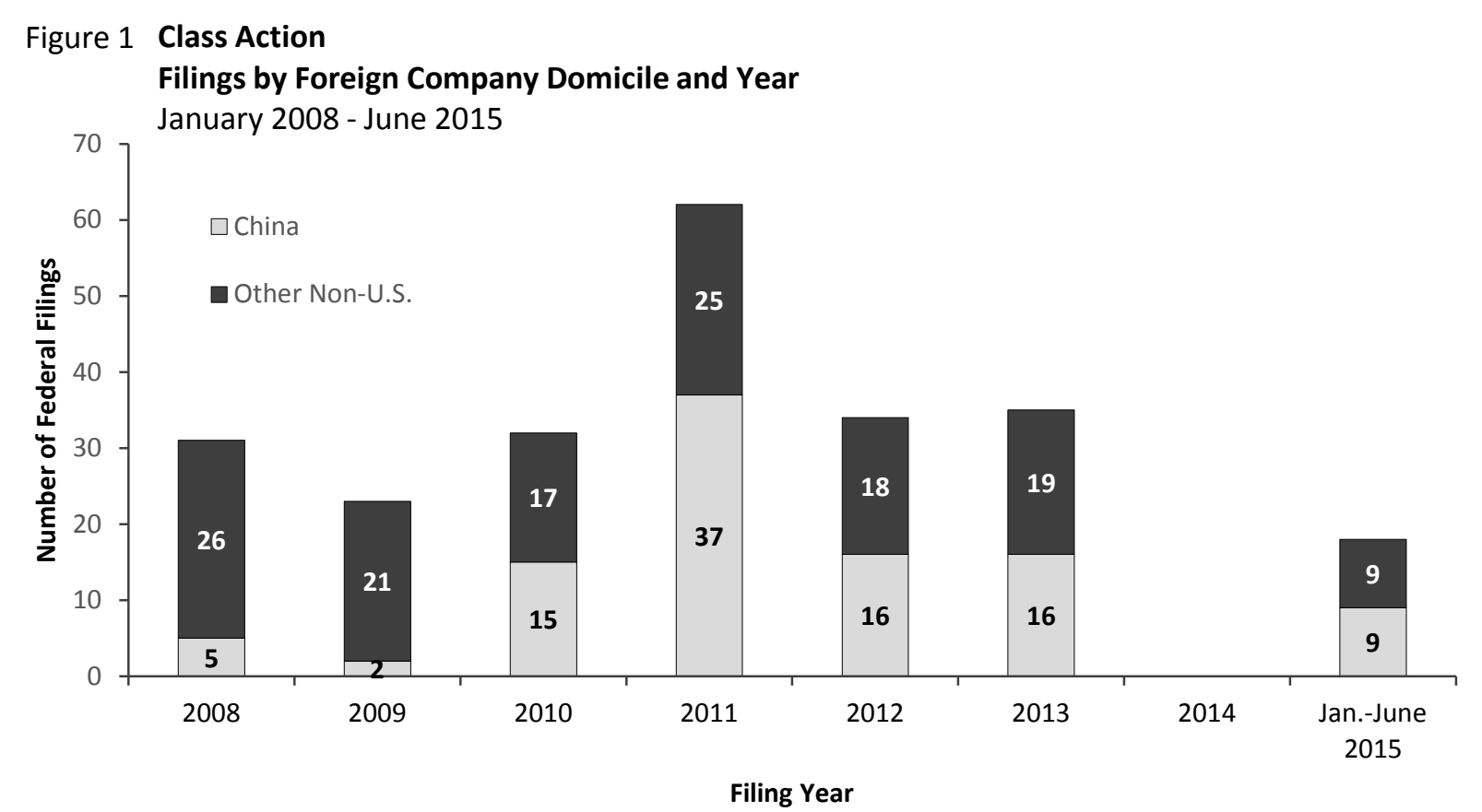

Sources: Comolli \& Starykh (2014) (for years 2008-2013); LaCroix (2015) (for 2015).

foreign jurisdiction where listing occurs; the issuer could be incorporated anywhere (for example, the Cayman Islands or even China itself) and thus governed by that jurisdiction's corporate law, not the corporate law of any state in the United States.

${ }^{12}$ This surge in lawsuits is attributable to a number of Chinese reverse mergers (LaCroix 2014). Thirtyone of the thirty-seven filings in 2011 against Chinese companies were related to Chinese reverse mergers (Cornerstone Research 2015: 4). 


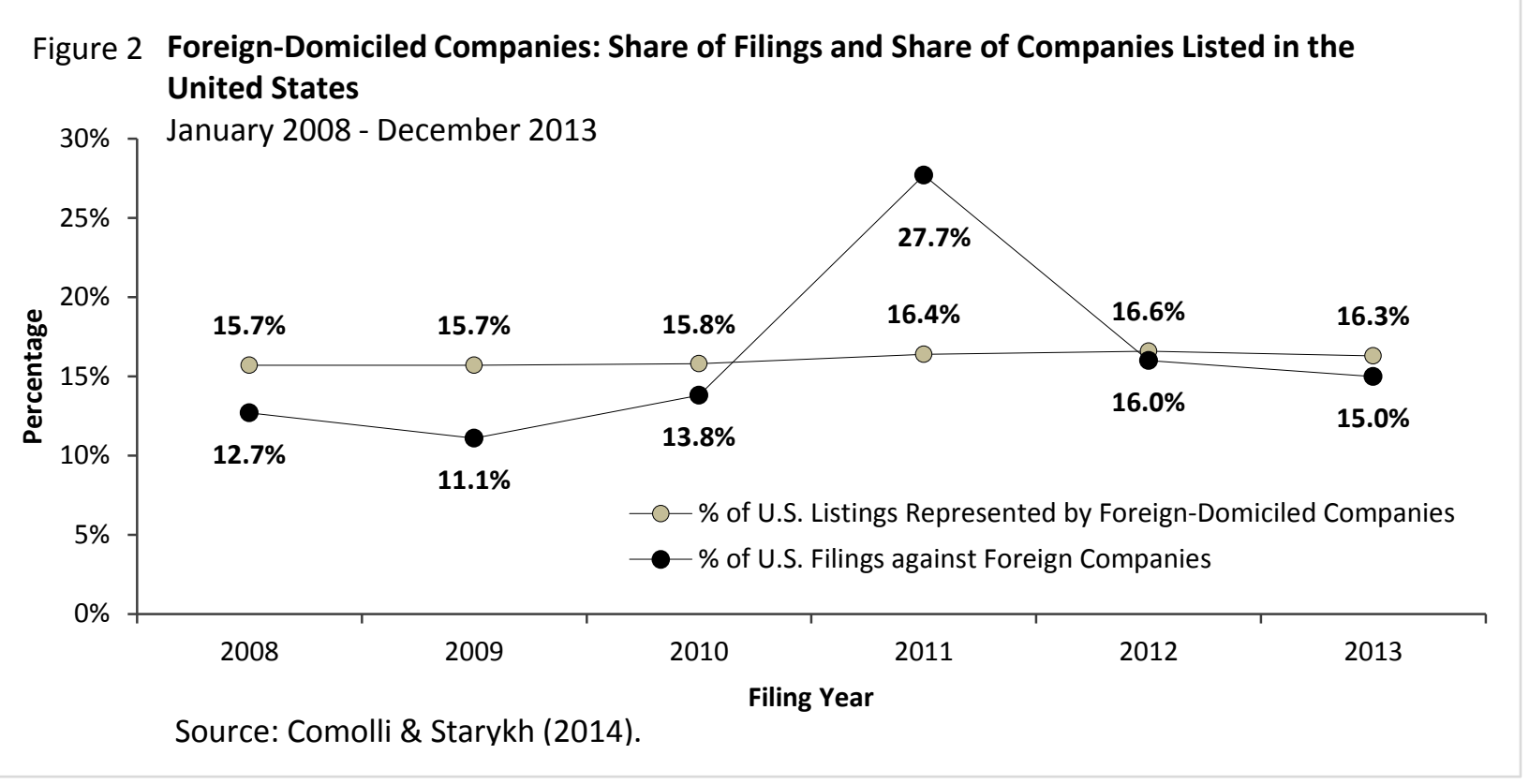

The SCAC web site lists a total of eighty-eight cases involving Chinese companies filed between January 2011 and October 2015 inclusive. The result is pending or unknown in thirty-five cases. Twenty-five cases were dismissed and twenty-eight were settled. In three cases, plaintiffs won: in each case, a default judgment (see Figure 3 ). 
Figure 3 Securities Class Actions Involving Chinese Companies

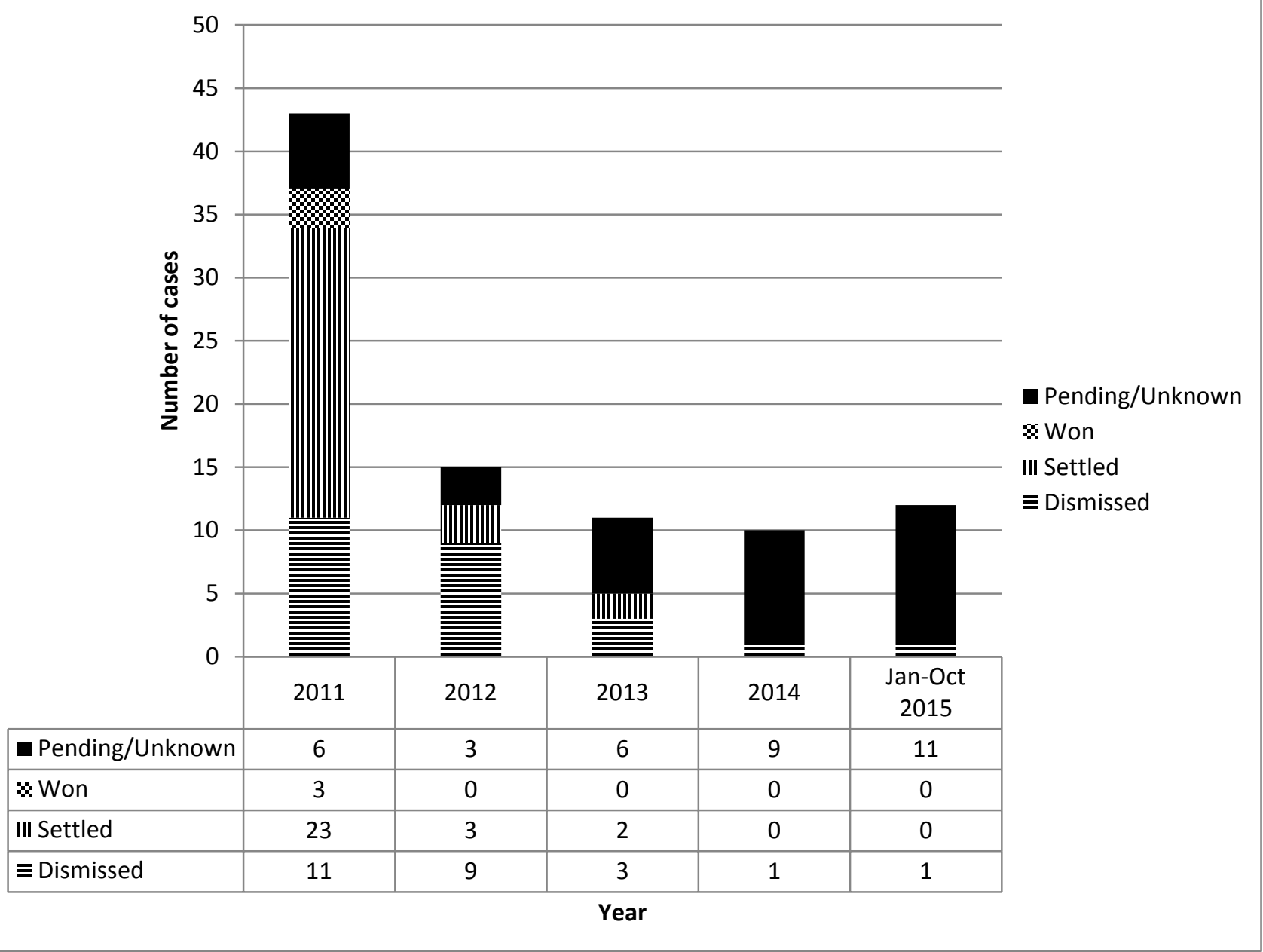

It is unlikely that plaintiffs will ever collect from the default judgment. Such cases can therefore be excluded from cases where bonding had bite. Similarly, the dismissed cases imposed no penalty on corporate management beyond the cost of defending the suits, which would have been borne by the company and not by individuals. We are left, therefore, with the settled cases.

If all the settled cases resulted in monetary damages being paid by individuals, one could find a modest bonding effect: fully twenty-three out of forty-three cases in 2011, when lawsuits surged because of reverse mergers, although only two of fifteen and three of eleven cases in 2012 and 2013 respectively, and none so far in 2014 and 2015 (to the extent the outcome is known). The problem, however, is that this is almost certainly not happening; the consensus of those who have researched the question is that insiders directors, executive officers and controlling shareholders, or in other words those who 
need to be deterred - personally pay a vanishingly small proportion of any settlement amount (less than one percent) (Coffee 2006: 1534-5). ${ }^{13}$

Might settlements with Chinese companies not follow this pattern? Given that it is difficult as a practical matter to force individual Chinese defendants to pay, there is no reason for thinking that plaintiffs will be more likely in Chinese cases than otherwise to insist on individual liability as part of a settlement. On the other hand, a substantial proportion of payments in US class action settlements comes from directors' and officers' insurance ( $\mathrm{D} \& \mathrm{O}$ insurance). Here Chinese corporate insider defendants appear to be very different from their US counterparts; apparently only five per cent of Chinese A-share listed companies have purchased D\&O insurance for their officers and directors (Jia 2015, citing an unnamed report). Nevertheless, given that cases that are not dismissed appear almost always to be settled, it is plausible to suppose that the individual defendants are willing to settle because they do not feel harmed by the terms.

\subsection{Public enforcement}

Experience to date in the realm of public enforcement has not been encouraging. In his study of Chinese firms listed in Hong Kong, Cai (2007) finds that the Hong Kong Stock Exchange and Hong Kong authorities in general have been weak in enforcement actions against Chinese companies.

To assess public enforcement in the United States, I examined all civil suits brought in federal courts by the Securities and Exchange Commission involving companies headquartered in China for which there was a result on or after 1 January 2011. ${ }^{14}$ I found no such cases for 2011 and 2012. From 2013 to October 2015 inclusive, there were twelve actions involving Chinese companies. These actions, however, involved only nine cases of fraud perpetrated upon investors. ${ }^{15}$ In six of those nine cases, individual perpetrators who were Chinese citizens resident in China ended up paying a penalty. ${ }^{16}$

${ }^{13}$ A more recent study concludes:

Out-of-pocket payments by officers or directors are rare. Among cases filed from 2006 through 2010, $2 \%$ of settlements have included an out-of-pocket payment by an officer and none has involved a payment by an outside director. From 2000 through $2005,5.45 \%$ of settlements included payments by officers and $2 \%$ included payments by outside directors. (Klausner et al. 2013: 8)

${ }^{14}$ These cases are listed on the SEC's web site at www.sec.gov/litigation.shtml.

${ }^{15}$ According to the bonding hypothesis, the importance of bonding lies in its assurance it provides to potential investors that the company and its management will follow relevant disclosure rules and not expropriate shareholders. As a result, investors are more willing to trust management with their money and this lowers the company's cost of capital. For this reason, for the purposes of this project I 


\section{Implications and Conclusion}

The results of this survey of private and public enforcement of securities laws against Chinese cross-listed companies do not, unfortunately, speak for themselves. The results for private enforcement actions suggest that skepticism about the actual bonding effect of cross-listing is justified. In no case is it clear that individual wrongdoers actually suffered adverse consequences.

The number of public enforcement actions appears, as an absolute number, to be small; whether this is good or bad depends on one's assessment of the number of actions there should have been. Among the public enforcement actions brought for fraud perpetrated upon investors, two thirds resulted in Chinese citizens resident in China paying a penalty, a result that suggests a stronger than expected bonding effect. At the same time, Chinese executives have not suffered anything worse than liability for monetary amounts and temporary bans from serving as officer or director. Since U.S. authorities could not have forced the defendants to pay the penalty, the result suggests that some other factor - perhaps the desire to travel to or otherwise continue to do business in the United States - makes paying the penalty preferable to not paying it.

On the whole, it appears that the actual bonding effect of cross-listing by Chinese companies is greater than zero, but not by much. Investors should take seriously the disclosures in the Risk Factors section of the prospectuses of Chinese companies to the effect that it will be difficult to hold companies and their executives accountable under U.S. law. To the extent that the stock prices of those companies incorporate a bonding premium of any significance, they are therefore probably overpriced. This in turn suggests that stock markets do not efficiently reflect all publicly available information; ${ }^{17}$ instead, it is more likely that markets treat cross-listed shares similarly

have excluded cases of insider trading and market manipulation, since those offenses do not amount to improper diversions of corporate funds that expropriate shareholders.

${ }^{16}$ I have assumed that where a case was disposed of by a settlement or other form of consent, the penalty was in fact paid, and that where a defendant failed to appear and the case was disposed of by a default judgment, the penalty was not in fact paid. I am looking only at penalties paid by individuals, not by companies, on the theory that only the former penalties act as the realistic deterrent required by the bonding hypothesis. As noted in Section 2.3.2.1 above, sanctions on companies hit the wrong target; they merely add insult to injury by hurting the very investors intended to be protected (Arlen 2007:3).

${ }^{17}$ This is not inherently implausible, despite the obvious objection that anyone in possession of publicly available information that has not been reflected in stock prices should be able to make a killing. The key is to know which publicly available information is already reflected in stock prices and which is not. A recent study finds, for example, that over the last fifteen years, U.S. Supreme Court decisions have been responsible for changes in wealth of over $\$ 140$ billion. Yet the study also finds that the informational 
- that is, as making companies and management equally accountable under U.S. law -regardless of the country in which the company is based.

content of those decisions has been incorporated only very slowly in the price of affected securities, implying "a market ripe for arbitrage where an event-based trading strategy could be successful." (Katz et al. 2015: 1) 


\section{Bibliography}

Arlen, Jennifer 2007. 'Public Versus Private Enforcement of Securities Fraud', available at http://weblaw.usc.edu/assets/docs/Arlen.pdf

Autohome, Inc. Form F-1 Registration Statement, 5 Nov. 2014, available at

https://www.sec.gov/edgar/searchedgar/companysearch.html

Cai, Hua. 2007. 'Bonding, Law Enforcement, and Corporate Governance in China', Stanford Journal of Law, Business \& Finance 13 (Fall): 82-119.

Cheng, Beiting, Srinivasan, Suraj, and Yu, Gwen 2014. 'Securities Litigation Risk for Foreign Companies Listed in the U.S.', available at http://ssrn.com/abstract=2163864

Clarke, Donald C. 2004. 'The Enforcement of United States Court Judgments in China: A Research Note', available at http://ssrn.com/abstract=943922

Coffee, John C., Jr. 1999. 'The Future as History: The Prospects for Global Convergence in Corporate Governance and Its Implications.', Northwestern University Law Review 93 (3): $641-708$

Coffee, John C., Jr. 2002. 'Racing Towards the Top? The Impact of Cross-Listings and Stock Market Competition on International Corporate Governance', Columbia Law Review 102: 1757-1831

Coffee, John C., Jr. 2006. 'Reforming the Securities Class Action: An Essay on Deterrence and Its Implementation,' Columbia Law Review 106: 1534-86

Comolli, Renzo and Starykh, Svetlana 2014. Recent Trends in Securities Class Action Litigation: 2013 Full-Year Review. 21 January. NERA Economic Consulting, http://www.nera.com/publications/archive/2014/recent-trends-in-securities-class-actionlitigation-2013-fully.html [http://bit.ly/nera2014]

Cornerstone Research 2015. Securities Class Action Filings: 2014 Year in Review. https://www.cornerstone.com/GetAttachment/52bfaa16-ff84-43b9-b7e78b2c7ab6df43/Securities-Class-Action-Filings-2014-Year-in-Review.pdf [http://bit.ly/classactions2014]

Davis, Marc 2015. 'Chinese Companies Doing Business in the US Build Barriers to Legal Remedies', ABA Journal, 1 Nov., available at http://www.abajournal.com/magazine/article/chinese_companies_doing_business_in_th e_us_build_barriers_to_legal_remedi [http://bit.ly/1mmp97R].

Dodd, Olga 2013. 'Why Do Firms Cross-List Their Shares on Foreign Exchanges? A Review of Cross-Listing Theories and Empirical Evidence', July 2013, available at http://ssrn.com/abstract=2271371 
Jia, Hui 2015. 'D\&O Liability Insurance: Legal Issues under the PRC Laws', Lexology, 8 May, available at http://www.lexology.com/library/detail.aspx?g=47af7198-c36d-4769-aoc86a64edagbe12 [http://bit.ly/jiahui2015]

Daniel Martin Katz, Michael J. Bommarito II, Tyler Soellinger, and James Ming Chen. 'Law on the Market? Evaluating the Securities Market Impact of Supreme Court Decisions', 24 Aug. (Version 1.o1), http://ssrn.com/abstract $=2649726$

Klausner, Michael; Hegland, Jason; and Goforth, Matthew. How Protective is DEO Insurance in Securities Class Actions? - An Update. 23 April, http://ssrn.com/abstract $=\mathbf{2 2 6 0 8 1 5}$

LaCroix, Kevin 2015. 'Year-to-Date Securities Suit Filings Disproportionately Involve NonU.S. Companies', The DEO Diary, 15 June, http://www.dandodiary.com/2015/o6/articles/securities-litigation/year-to-date-securitiessuit-filings-disproportionately-involve-non-u-s-companies/ [http://bit.ly/LaCroix2015]

Leuz, Christian 2003. 'Discussion of ADRs, Analysts, and Accuracy: Does Cross - Listing in the United States Improve a Firm's Information Environment and Increase Market Value?", Journal of Accounting Research 41: 347-62

Leuz, Christian and Verrecchia, Robert 200o. 'The Economic Consequences of Increased Disclosure', Journal of Accounting Research 38 (Supplement): 91-124

Licht, Amir N. 2003. 'Cross-Listing and Corporate Governance: Bonding or Avoiding', Chicago Journal of International Law 4 (2003): 141-64

Licht, Amir N., Poliquin, Christopher, Siegel, Jordan I., and Li, Xi 2013. 'What Makes the Bonding Stick? A Natural Experiment Involving the Supreme Court and Cross-Listed Firms', Harvard Business School Working Paper 11-072, 27 Aug., available at http://ssrn.com/abstract $=1744905$

Liu, Li Xian, Jiang, Fuming, and Sathye, Milinde 2015. 'Does Bonding Really Bond? CrossListing Location, Corporate Governance and Value of Chinese Firms', 28 Jan., available at http://ssrn.com/abstract=2556689

MacNeil, Iain 2001. 'Competition and Convergence in Corporate Regulation: The Case of Overseas Listed Companies', 1 Aug., available at http://ssrn.com/abstract $=278508$

Peng, Mike W. and Blevins, Dane P. 2012. 'Why Do Chinese Firms Cross-List in the United States?', in Rasheed, Abdul A. and Yoshikawa, Toru (eds.), The Convergence of Corporate Governance: Promise and Prospects (New York: Palgrave McMillan, 2012): 255-71 
Rock, Edward B. 1998. 'Mandatory Disclosure as Credible Commitment: Going Public, Opting In, Opting Out and Globalization', 9 Sept., abstract available at http://ssrn.com/abstract=145528 (full text no longer available)

Rock, Edward B. 2002. 'Securities Regulation as Lobster Trap: A Credible Commitment Theory of Mandatory Disclosure', Cardozo Law Review 23 (2002): 675-704

Rosier, Kevin 2015. China's Great Legal Firewall: Extraterritoriality of Chinese Firms in the United States. US-China Economic and Security Review Commission, May 5, available at http://origin.www.uscc.gov/sites/default/files/Research/Extraterritoriality\%20of\%2oChin ese\%2oFirms_Research\%2oReport_o.pdf [http://bit.ly/rosier2015]

Shen, Hongbo, Liao, Li, and Liao, Guanmin 2010. 'Cross-Listing and Bonding Premium: Evidence from Chinese Listed Companies', Front. Bus. Res. China 4(2): 171-84

Siegel, J. 2005. 'Can Foreign Firms Bond Themselves Effectively by Renting US Securities Laws?', Journal of Financial Economics 75: 319-59

Sikochi, Anywhere 2014. 'The Effect of Shareholder Litigation Risk on the Information Environment: The Case of Cross-Listed Firms', available at http://ssrn.com/abstract=2515091

Stulz, René M. 'Globalization, Corporate Finance, and the Cost of Capital', Journal of Applied Corporate Finance 12 (3): 8-25

Sun, Qian, Tong, Wilson H.S., and Wu, Yujun 2006. 'Bonding Premium as a General Phenomenon', available at http://ssrn.com/abstract=890962 